\title{
Attitude Control of Planar End-Effector and Estimation of Contact Point Using Parallel Mechanism
}

\author{
Ryogo Kubo Student Member (Keio University, kubo@sum.sd.keio.ac.jp) \\ Kouhei Ohnishi Senior Member (Keio University, ohnishi@sd.keio.ac.jp)
}

Keywords: parallel mechanism, attitude control, compliance control, haptics, environment recognition, reaction torque observer

Recently, many robots have been utilized in unknown environment, for example, slave robots of teleoperation systems, walking robots and so on. They are called environment-adaptive robots. In most teleoperation systems, slave manipulators are placed in unknown environment. In the case of walking robots, the paddle foot is a planar end-effector and road surface is unknown environment. They recognize shape of road surface and need to walk on rough terrain. Therefore, it is very important for the environment-adaptive robots to contact stably and to recognize unknown environment.

In this paper, a compliance controller of attitude of a planar endeffector is proposed to achieve stable contact with unknown environment. The robot utilized in this research has parallel mechanism as a whole as shown in Fig. 1, since the planar end-effector is supported by three arms. Virtual compliance models are inserted at the end of each arm for compliant motion of the end-effector. On the other hand, position control is also achieved for COG (center of gravity) of the end-effector.

Moreover, an estimation method of the contact point without sensors is presented. We assume that only face-to-point contact exists between the end-effector and unknown environment. Reaction torque observer is utilized to estimate reaction force from unknown

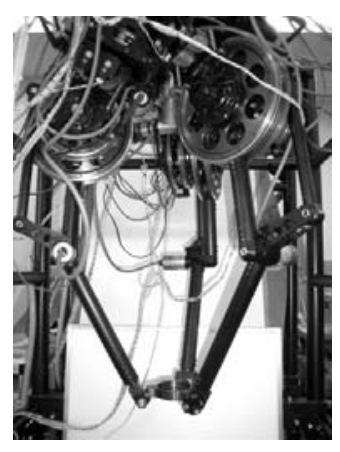

(a) overview

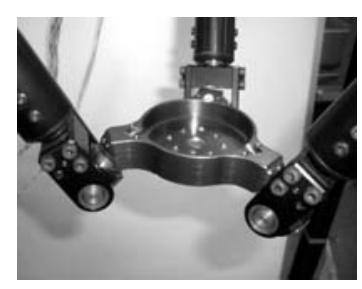

(b) end-effector
Fig. 1. Parallel-link manipulator environment. And excessive stress is not exerted on the robots and the environment by means of the proposed controller in the estimation.

We carried out some experiments by changing force feedback gain $K_{f}$. Fig. 2 shows comparison of accuracy in the estimation. $d$ is the distance between the environment and the estimation value. Estimation is achieved with a high degree of accuracy if $d$ is small. $\alpha$ means $z$-direction displacement of COG of the end-effector after the end-effector contacts the environment. If $\alpha$ increased or $K_{f}$ approaches zero, accuracy was improved as shown in Fig. 2. In this case, reaction force from the environment gets larger and ratio of force exerted on each arm can be detected more accurately. In the case of $K_{f}=1.0$ and $d=3.0 \mathrm{~mm}$, correct values were estimated in spite of not exerting excessive stress on the environment.

In this paper, face-to-point contact was realized by means of a planar end-effector instead of a spheral end-effector. We proposed compliance controller for attitude of a planar end-effector and an estimation method of the contact point. The validity of the proposed method was shown by the numerical and experimental results. Our new approach of contact motion can be widely applied to the robots using parallel mechanism.

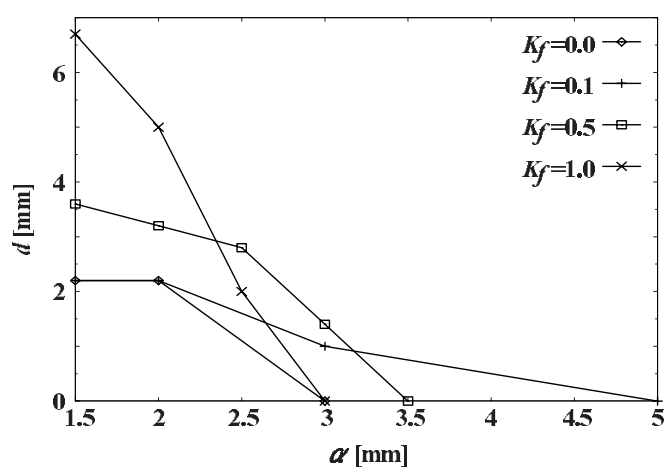

Fig. 2. Comparison of estimation accuracy 


\title{
パラレルメカニズムを用いた \\ 平面状エンドエフェクタの姿勢制御と接触位置の推定
}

学生員 久保 亮吾* 上級会員 大西 公平*

\author{
Attitude Control of Planar End-Effector and Estimation of Contact Point \\ Using Parallel Mechanism
}

Ryogo Kubo*, Student Member, Kouhei Ohnishi*, Senior Member

\begin{abstract}
Recently, many robots have been utilized in unknown environment, for example, slave robots of teleoperation systems, walking robots and so on. They are called environment-adaptive robots. It is very important for the environmentadaptive robots to contact stably and to recognize unknown environment. In this paper, a compliance controller of attitude of a planar end-effector is proposed to achieve stable contact with unknown environment. The robot utilized in this research has parallel mechanism as a whole, since the planar end-effector is supported by three arms. With the assumption that only face-to-point contact exists between the end-effector and unknown environment, an estimation method of the contact point without sensors is also proposed. Moreover, excessive stress is not exerted on the robots and the environment by means of the controller we propose, when the contact point is estimated. Our new approach of contact motion can be widely applied to the robots using parallel mechanism. The validity of the proposed method is shown by the numerical and experimental results.
\end{abstract}

キーワード：パラレルメカニズム, 姿勢制御, コンプライアンス制御, ハプティクス, 環境認識, 反力推定オブザーバ

Keywords: parallel mechanism, attitude control, compliance control, haptics, environment recognition, reaction torque observer

\section{1. 序 論}

近年，ロボットが人間の生活空間へと進出するにつれて ロボットが直接人間と接する機会が増えてきた。工場内と は異なりこのような環境下では，ロボットはあらかじめ決 められた動作をするだけではなく，未知の環境に対して柔 軟に軌道を修正し適応しなければならない。したがって, ロボットは人間や環境と安定な接触動作をすることが必要 であると考えられ，ロボットの接触安定性については多く の研究がなされてきた。Vukobratovićらら (1) は接触動作にお ける制御手法を受動的コンプライアンス制御と能動的コン プライアンス制御に大別し，さらに数種類に分類した上で 安定解析を行った。榊ら (2) は振動要素, 目標インピーダン スの設定值やモデル化誤差が接触安定性に影響を与えるこ とを示した。また，インピーダンス制御を 6 自由度の産業 用マニピュレータに実装し，実験を行った例もある ${ }^{(3)(4)}$ 。

多くの研究事例 (5) では, ロボットが環境と直接接触する 部分であるエンドエフェクタは点接触を前提とした球状エ

\footnotetext{
慶應義塾大学理工学部システムデザイン工学科

干 223-8522 横浜市港北区日吉 3-14-1

Department of System Design Engineering, Keio University

3-14-1, Hiyoshi, Kohoku-ku, Yokohama 223-8522
}

ンドエフェクタ等であった。例えば, 加藤ら ${ }^{(6)}$ は, 医師によ る乳ガンの触診を自動化する目的で乳ガン自動触診ロボッ 卜を製作し，臨床試験を行った。しかし，複数の触子を用 いて触診したとしても接触させる回数が膨大となり, 通常, 医師が触診に要する時間よりも多くの時間を要してしまう ことが問題とされた。このような事例においては，使用す るエンドエフェクタを平面にすれば，一度に広い領域をス キャンできるようになり，触診時間の短縮が期待できると 考えられる。また，パラレルメカニズム(7)を用いて各関節 のモータを根元に集中配置することで, アームを軽量化で き, 安全性が向上する。パラレルメカニズムは, 可動部が 並列に駆動される閉リンク機構のことであり，一般的に以 下のような特徴をもつ。

・複数のリンクで支持されるため，剛性が高い

・複数のアクチュエータで支持されるため, アクチュエー 夕にかかる負荷を分散させることができる

・可動域が広くない

本研究で用いるパラレルリンクマニピュレータは空間 6 自 由度に対して関節 9 自由度という圥長な構造をしているた め, パラレルメカニズム特有の特異姿勢が存在せず, 可動 域が比較的広い。

そこで本研究では, 平面状エンドエフェクタをパラレル 
メカニズムによって構成し, 面一点接触を仮定して環境と接 触させ，その接触位置を推定することを目的とする。平面 状エンドエフェクタを用いることで，面一面接触，面-線接 触，面一点接触の 3 種類の接触状態を実現できるが，本論文 ではその第一段階として面一点接触のみを扱うものとする。 最終的には, 面一面接触，面一線接触，面一点接触の 3 つの状 態を判別し，接触している環境の形状を把握できるように なることを目標としている。

また，推定の際に反力推定オブザーバ(8) を用いることで, センサレスでエンドエフェクタと環境との接触位置を推定 できる。さらに，ロボットや環境に大きな負荷を与えずに 接触位置を推定するために，エンドエフェクタの中心位置 に対しては位置制御，姿勢に対してはコンプライアンス制 御を行う手法を提案する。

以下に本論文の構成を示す。まず，次章で制御対象であ るパラレルリンクマニピュレータのモデル化を行う。次に, 第 3 章で接触位置の推定法を，第 4 章で環境と安定な接触 を行うための姿勢制御手法を提案する。第 5 章，第 6 章で はシミュレーションと実験により，提案する手法の有効性 を確認する。最後に第 7 章で結論を述べる。

\section{2. パラレルリンクマニピュレータのモデル化}

本研究では, 平面状のエンドエフェクタを実現するため, 図 1(a)に示すような 3 台の 3 リンクアームを有するパラ レルリンクマニピュレータを使用する。3 台のアームは同 構造であり，便宜上，各アームをそれぞれアーム A, B , C とする。また，平面状のエンドエフェク夕は図 1(b) のよう に各アームの先端にボールジョイント(9)を介して接続され ている。本章では，パラレルリンクマニピュレータを図 2 , 図 3，図4のようにモデル化する。

〈2・1〉3 リンクアームの運動学 図 2 において, $L_{1}$, $L_{2}, L_{3}$ はそれぞれリンク 1 ，リンク 2 , リンク 3 の長さ， $\theta_{1}, \theta_{2}, \theta_{3}$ はそれぞれ関節 1 , 関節 2 , 関節 3 の回転角度で ある。アームの先端位置ベクトルを $\boldsymbol{x}_{\text {arm }}=[x, y, z]^{T}$, アー ムの関節角べクトルを $\boldsymbol{\theta}_{\text {arm }}=\left[\theta_{1}, \theta_{2}, \theta_{3}\right]^{T}$ とすると, アー ムの順運動学は以下のように記述される。

$$
\boldsymbol{x}_{\text {arm }}=\left[\begin{array}{c}
\left(L_{2} \sin \theta_{2}+L_{3} \sin \theta_{3}\right) \cos \theta_{1} \\
\left(L_{2} \sin \theta_{2}+L_{3} \sin \theta_{3}\right) \sin \theta_{1} \\
L_{1}+L_{2} \cos \theta_{2}+L_{3} \cos \theta_{3}
\end{array}\right] .
$$

(1) 式の両辺を時間微分することにより，(2)式が得られる。

$$
\dot{\boldsymbol{x}}_{\text {arm }}=\boldsymbol{J}_{\text {arm }} \dot{\boldsymbol{\theta}}_{\text {arm }}
$$

ここで， $\boldsymbol{J}_{\text {arm }}$ は 3 リンクアームの関節角速度ベクトルと先 端速度べクトルを関係づけるヤコビ行列である。

〈2・2〉 パラレルリンクマニピュレータの運動学 3 台 の 3 リンクアームはベースリンクに図 3 で示すように取り 付けられている。ここで， $r_{\text {base }}$ はベースリンクの半径であ る。アーム座標系 $\left(\Sigma_{A}, \Sigma_{B}, \Sigma_{C}\right)$ からべース座標系 $\left(\Sigma_{W}\right) へ$ の回転行列，並進べクトルをそれぞれ ${ }^{W} \boldsymbol{R}_{\text {arm }},{ }^{W} \boldsymbol{p}_{\text {arm }}$ とする

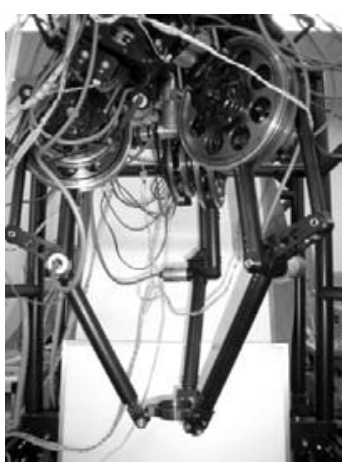

(a) overview

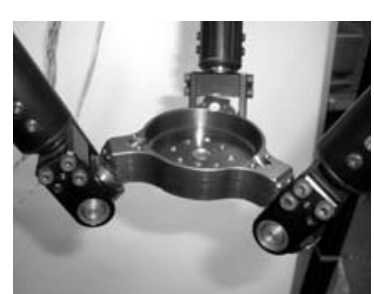

(b) end-effector
図 1 パラレルリンクマニピュレータ

Fig. 1. Parallel-link manipulator
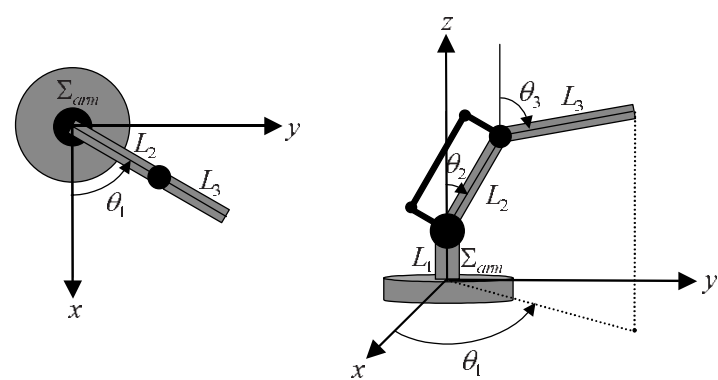

図２３リンクアームのモデル化

Fig. 2. Modeling of 3-link arms

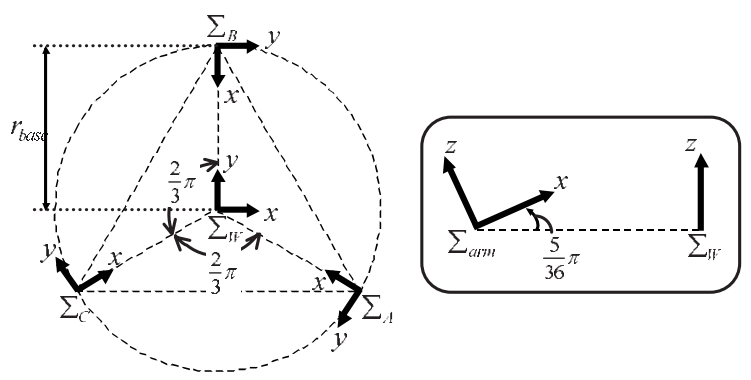

図 3 アーム座標系とベース座標系の関係

Fig. 3. Relationship between arm coordinate system and base coordinate system

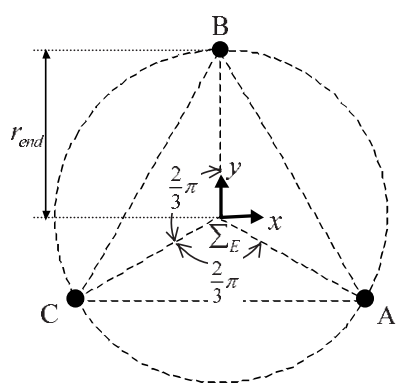

図 4 エンドエフェクタ座標系

Fig. 4. Definition of end-effector coordinate system

と, ベース座標系に扔けるアームの先端位置ベクトル ${ }^{W} \boldsymbol{x}_{\text {arm }}$ は (3) 式のように表される。右下添え字の arm はアーム A, B，Cに対応している。 


$$
{ }^{W_{x_{a r m}}}={ }^{W} \boldsymbol{R}_{\text {arm }} \boldsymbol{x}_{\text {arm }}+{ }^{W} \boldsymbol{p}_{\text {arm }}
$$

ベース座標系におけるアームの先端速度ベクトルを $\dot{X}=$ $\left[{ }^{W_{\boldsymbol{x}_{A}}}{ }^{T},{ }^{W} \dot{\boldsymbol{x}}_{\boldsymbol{B}}{ }^{T},{ }^{W} \dot{\boldsymbol{x}}_{\boldsymbol{C}}{ }^{T}\right]^{T}$, アームの関節角速度ベクトルを $\dot{\boldsymbol{\Theta}}=$ $\left[\dot{\boldsymbol{\theta}}_{\boldsymbol{A}}{ }^{T}, \dot{\boldsymbol{\theta}}_{\boldsymbol{B}}{ }^{T}, \dot{\boldsymbol{\theta}}_{\boldsymbol{C}}{ }^{T}\right]^{T}$ とすると(4) 式が得られる。

$$
\dot{X}=J_{r} \dot{\Theta}
$$

ここで， $\boldsymbol{J}_{\boldsymbol{r}}$ はアームの関節角速度ベクトルとアームの先端 速度ベクトルを関係づけるヤコビ行列である。

図 4 より, エンドエフェクタの中心位置 ${ }^{W} \boldsymbol{p}_{\boldsymbol{E}}$, エンドエ フェクタ座標系 $\left(\Sigma_{E}\right)$ の $x, y, z$ 軸正方向の単位ベクトル $\boldsymbol{N}$ (単位法線ベクトル), $\boldsymbol{S}$ (単位スライデイングベクトル), $\boldsymbol{A}$ (単位アプローチベクトル) は (5)-(9) 式のように求めら れる。 $r_{\text {end }}$ はエンドエフェクタの半径である。

$$
\begin{aligned}
& { }^{W} p_{E}=\frac{{ }^{W} x_{A}+{ }^{W} x_{B}+{ }^{W} x_{C}}{3} . \\
& \boldsymbol{S}=\frac{{ }^{W} \boldsymbol{x}_{\boldsymbol{B}}-{ }^{W} \boldsymbol{p}_{\boldsymbol{E}}}{r_{\text {end }}} . \\
& \boldsymbol{A}_{t}=\left(\frac{{ }^{W} \boldsymbol{x}_{\boldsymbol{A}}-{ }^{W} \boldsymbol{p}_{\boldsymbol{E}}}{r_{\text {end }}}\right) \times S \\
& \boldsymbol{A}=\frac{\boldsymbol{A}_{t}}{\left|\boldsymbol{A}_{t}\right|} \text {. } \\
& N=S \times A
\end{aligned}
$$

ベース座標系におけるエンドエフェクタ中心の速度べクト ルを $\dot{\boldsymbol{P}}=\left[{ }^{W} \dot{\boldsymbol{p}}_{\boldsymbol{E}}{ }^{T}, \omega_{x}, \omega_{y}, \omega_{z}\right]^{T}$ とすると, (10) 式が成り立つ。 ただし， $\omega_{x}, \omega_{y}, \omega_{z}$ はそれぞれエンドエフェクタ座標系の $x$ 軸, $y$ 軸, $z$ 軸まわりの回転角速度とする。

$$
\dot{\boldsymbol{X}}=\boldsymbol{J}_{v} \dot{\boldsymbol{P}}
$$

ここで， $J_{v}$ はエンドエフェクタ中心の速度ベクトルとアー ムの先端速度べクトルを関係づけるヤコビ行列である。

したがって，パラレルリンクマニピュレータの順運動学 は (11) 式, 逆運動学は (12) 式で表せる。

$$
\begin{aligned}
\dot{\boldsymbol{P}} & =J_{v}{ }^{+} \dot{\boldsymbol{X}}=J_{v}{ }^{+} J_{r} \dot{\Theta}=J \dot{\Theta} \\
\dot{\Theta} & =J^{+} \dot{\boldsymbol{P}} \ldots \ldots \ldots \ldots
\end{aligned}
$$

ここで，Jはアームの関節角速度ベクトルとエンドエフェ クタ中心の速度ベクトルを関係づけるヤコビ行列であり， $J_{v}{ }^{+}, J^{+}$はそれぞれ $J_{v}, J$ の擬似逆行列を表す。

〈2·3〉 動 力 学 まず, パラレルリンクマニピュレー タの閉ループ構造をエンドエフェクタを 3 等分することに より仮想的に切断し，開ループ木構造モデルを考える ${ }^{(10)}$ 。 次に, この開ループ木構造モデルの動力学方程式を NewtonEuler 法を用いて求める。これに拘束条件 $\boldsymbol{f}(\boldsymbol{\theta})=\mathbf{0}$ を加え ると, パラレルリンクマニピュレータの動力学方程式は (13) 式のように表せる。

$$
\boldsymbol{M} \ddot{\boldsymbol{\theta}}+\boldsymbol{C}(\boldsymbol{\theta}, \dot{\boldsymbol{\theta}})=\tau+\boldsymbol{J}_{\boldsymbol{m}}{ }^{T} \boldsymbol{f}_{\boldsymbol{e}}^{e x t}+\boldsymbol{J}_{\boldsymbol{c}}{ }^{T} \lambda
$$

ただし， $\boldsymbol{M}$ は慣性行列， $\boldsymbol{C}(\boldsymbol{\theta}, \dot{\boldsymbol{\theta}})$ は重力・速度依存項， $\boldsymbol{\tau}$ は 関節トルク $\boldsymbol{J}_{\boldsymbol{m}}$ は開ループ木構造モデルにおいて関節角速

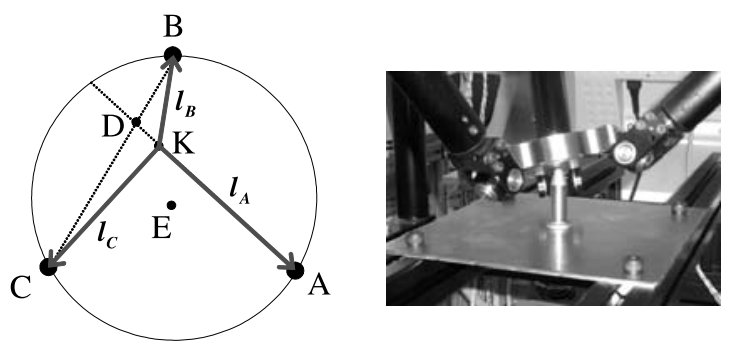

図 5 接触位置の推定

Fig. 5. Estimation of contact point

度ベクトルとエンドエフェクタ中心の速度ベクトルを関係 づけるヤコビ行列, $f_{e}^{e x t}$ はエンドエフェクタ中心に加わる 外力, $\lambda$ は拘束力, $J_{c}=\frac{\partial f}{\partial \theta}$ である。

\section{3. 接触位置推定法}

本章では，3 リンクアーム A, B, C の先端の位置情報と 反力推定オブザーバからセンサレスで獲得する力情報を用 いて，エンドエフェクタと環境との接触位置を推定する方 法を提案する。

〈3・1〉 $x, y$ 座標の推定 図 5 において, 点 $\mathrm{E}$ がエン ドエフェクタの中心であり, 点 $\mathrm{A}$, 点 $\mathrm{B}$, 点 $\mathrm{C}$ はそれぞれ アーム $\mathrm{A}$, アーム $\mathrm{B}$, アーム $\mathrm{C}$ の先端位置, 点 $\mathrm{K}$ は環境 との接触位置を表す。接触位置から各アーム先端までのべ クトルを $l_{A}, l_{B}, l_{C}$ とし, 各アーム先端に加わる力を $f_{A}$, $f_{B}, f_{C}$, 接触位置に加わる力を $f_{K}$ とする。エンドエフェ クタが静止している場合, エンドエフェクタの力のつり合 いは (14) 式，モーメントのつり合いは (15) 式で表される。

$$
\begin{aligned}
& f_{A}+f_{B}+f_{C}=f_{K} \cdots \cdots \cdots \cdots \\
& l_{A} \times f_{A}+l_{B} \times f_{B}+l_{C} \times f_{C}=O
\end{aligned}
$$

ベース座標系における点 $\mathrm{K}$ の位置を ${ }^{W} \boldsymbol{x}_{\boldsymbol{K}}$ とすると, 式は (16) 式と書き換えられる。

$$
\begin{aligned}
{ }^{W} x_{K} \times f_{K}= & { }^{W} x_{A} \times f_{A}+{ }^{W} x_{B} \times f_{B} \\
& +{ }^{W} x_{C} \times f_{C} \ldots \ldots \ldots \ldots
\end{aligned}
$$

第 1 章で述べたように, 本研究では環境とエンドエフェ クタの接触状態として点接触のみを仮定する。また, 計算 を簡略化するため, エンドエフェク夕に加わる外力は $z$ 方 向のみと仮定する。したがって, 次章で説明する反力推定 オブザーバより得られる力情報は $z$ 方向のみを採用し， $x$, $y$ 方向は全て $0 \mathrm{~N}$ とする。以上の仮定から，(16) 式の右辺 を $\boldsymbol{M}=\left[M_{x}, M_{y}, M_{z}\right]^{T}$ とすると, (16) 式は以下のように簡 略化できる。

$$
\begin{aligned}
& f_{K z} x_{K y}=M_{x} \\
& f_{K z} x_{K x}=-M_{y}
\end{aligned}
$$

ただし， $f_{K z}$ は $f_{\boldsymbol{K}}$ の $z$ 成分， $x_{K x}, x_{K y}$ はそれぞれ ${ }^{W} \boldsymbol{x}_{\boldsymbol{K}}$ の $x, y$ 成分である。 
$n$ 回の実験データを (19)-(21) 式として最小自乗法を用い ると，(14)，(17)，(18) 式から接触位置は，(22), (23) 式の ように求まる。

$$
\begin{aligned}
\boldsymbol{f}_{\boldsymbol{K} z} & =\left[f_{K z 1}, f_{K z 2}, \cdots, f_{K z n}\right]^{T} \\
\boldsymbol{M}_{\boldsymbol{x}} & =\left[M_{x 1}, M_{x 2}, \cdots, M_{x n}\right]^{T} \\
\boldsymbol{M}_{\boldsymbol{y}} & =\left[M_{y 1}, M_{y 2}, \cdots, M_{y n}\right]^{T} \\
x_{K y} & =\left(\boldsymbol{f}_{K z}{ }^{T} \boldsymbol{f}_{K z}\right)^{-1} \boldsymbol{f}_{\boldsymbol{K} z}{ }^{T} \boldsymbol{M}_{\boldsymbol{x}} \cdots \\
x_{K x} & =-\left(\boldsymbol{f}_{K z}{ }^{T} \boldsymbol{f}_{K z}\right)^{-1} \boldsymbol{f}_{\boldsymbol{K} z}{ }^{T} \boldsymbol{M}_{\boldsymbol{y}}
\end{aligned}
$$

$\langle\mathbf{3} \cdot 2\rangle z$ 座標の推定 接触位置の $z$ 座標 $x_{K z}$ はエンド エフェクタの平面方程式から以下のように求められる。

$$
\begin{aligned}
& x_{K z}=\frac{1}{c}\left(1-a x_{K x}-b x_{K y}\right) \text {. } \\
& {\left[\begin{array}{l}
a \\
b \\
c
\end{array}\right]=\left[\begin{array}{l}
{ }^{{ }} \boldsymbol{x}_{\boldsymbol{A}}{ }^{T} \\
{ }^{T} \boldsymbol{x}_{\boldsymbol{B}}{ }^{T} \\
{ }^{{ } \boldsymbol{x}_{\boldsymbol{C}}{ }^{T}}
\end{array}\right]^{-1}\left[\begin{array}{l}
1 \\
1 \\
1
\end{array}\right]}
\end{aligned}
$$

\section{4. 制御系の構成}

本章では，接触位置の推定を行うにあたり構築した制御 系について説明する。

〈4・1〉 姿勢のコンプライアンス制御コンプライアン ス制御は，任意のインピーダンスモデルを設定することに より，ロボットに所望のインピーダンス特性を実現させる 制御方法である(11)。また，外界から力を受けた場合にはそ の外力に倣うように軌道補正を行う制御系であるため，口 ボットは高剛性の環境と接触しても挙動が振動的になるこ となく接触状態を維持できる。本研究では, エンドエフェ クタの中心位置に対しては位置制御，姿勢に対してはコン プライアンス制御を行う。図 6 に提案した制御器を示す。

位置制御に基づくコンプライアンス制御では, 外力 $\boldsymbol{f}^{\text {ext }}=$ $\left[f_{A}{ }^{T}, f_{B}{ }^{T}, f_{C}{ }^{T}\right]^{T}$ を位置, 速度, 加速度に変換する必要があ る。本研究では，アーム A， B，Cの先端にそれぞれ (26) 式のようにコンプライアンスモデルを設定することにより 姿勢のコンプライアンス制御を実現する。

$$
M_{c} \ddot{x}_{c}^{c m d}+D_{c} \dot{x}_{c}^{c m d}+K_{c} x_{c}^{c m d}=K_{f} f^{e x t} .
$$

ここで, $M_{c}, D_{c}, K_{c}$ はそれぞれ仮想インピーダンス特性の 慣性項，粘性係数，ばね定数であり， $K_{f}$ は力フィードバッ クゲインである。

コンプライアンス制御器の出力は以下のように表される。 たたし, 中間変数 $\boldsymbol{x}_{\boldsymbol{c}}=\left[\boldsymbol{x}_{\boldsymbol{c} A}{ }^{T}, \boldsymbol{x}_{\boldsymbol{c} B}{ }^{T}, \boldsymbol{x}_{\boldsymbol{c} C} \boldsymbol{C}^{T}\right]^{T}$ は (27) 式のよ うに表される。

$$
\begin{aligned}
x_{c} & =x^{r e s}+x_{c}^{c m d} \ldots \ldots \\
p_{c} & =\frac{x_{c A}+x_{c B}+x_{c C}}{3} \\
S_{c}^{d} & =\frac{x_{c B}-p_{c}}{r_{\text {end }}} \ldots \ldots
\end{aligned}
$$

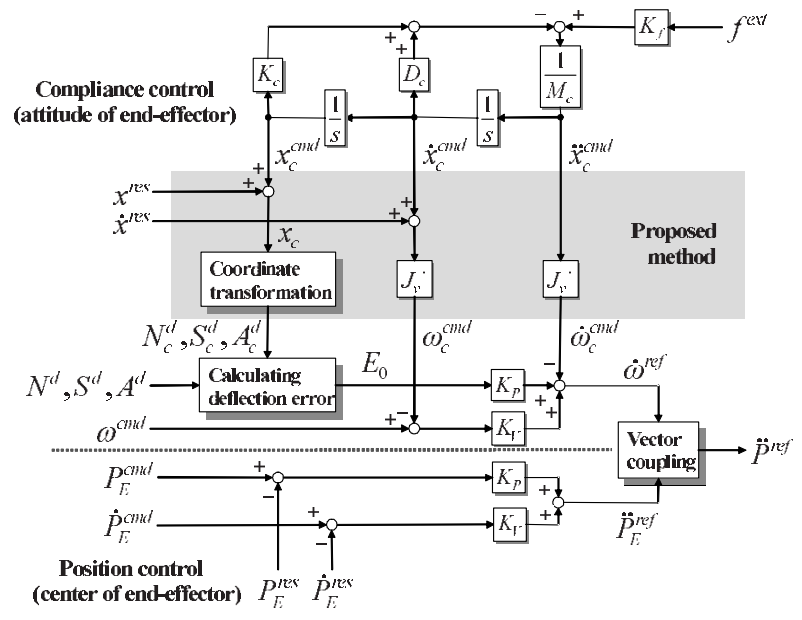

図 6 提案する制御器

Fig. 6. Proposed controller

$$
\begin{aligned}
& A_{t c}=\left(\frac{x_{c A}-p_{c}}{r_{e n d}}\right) \times S_{c}^{d} \ldots \ldots \\
& A_{c}^{d}=\frac{A_{t c}}{\left|A_{t c}\right|} \ldots \ldots \ldots \ldots \ldots \ldots \\
& N_{c}^{d}=S_{c}^{d} \times A_{c}^{d} \ldots \ldots \ldots \ldots \ldots \\
& {\left[\begin{array}{c}
\dot{p}_{c} \\
\omega_{c}^{c m d}
\end{array}\right]=J_{v}{ }^{+}\left(\dot{x}^{r e s}+\dot{x}_{c}^{c m d}\right)} \\
& {\left[\begin{array}{c}
\ddot{p}_{c} \\
\dot{\omega}_{c}^{c m d}
\end{array}\right]=J_{v}{ }^{+} \ddot{x}_{c}^{c m d} \ldots \ldots \ldots}
\end{aligned}
$$

また，姿勢の誤差べクトル $\boldsymbol{E}_{\boldsymbol{o}}$ は (35) 式のようにして求 められる。ただし, $N^{d}, S^{d}, A^{d}$ は姿勢の指令值である。

$$
E_{o}=\frac{1}{2}\left(N_{c}^{d} \times N^{d}+S_{c}^{d} \times S^{d}+A_{c}^{d} \times A^{d}\right) .
$$

以上より，PD 制御器を通した後の位置と姿勢を含む参照 值ベクトル $\ddot{P}^{r e f}$ は (36) 式となる。

$$
\ddot{P}^{r e f}=\left[\begin{array}{c}
\ddot{P}_{E}^{r e f} \\
\dot{\omega}^{r e f}
\end{array}\right]
$$

〈4・2〉 反力推定オブザーバコンプライアンス制御に はロボットに加わる外力の情報が必要となる。力センサは 温度などの外部環境の影響を受けやすく, 未知環境での作業 を行うロボットには適していない。そこで，図７に示す反 力推定オブザーバ（RTOB：Reaction Torque OBserver）を 用いてセンサレスで力情報を獲得する。反力推定オブザー バは外乱オブザーバ（JDOB：Joint space Disturbance OBserver) ${ }^{(12)}$ の推定外乱トルクから重力項, 摩擦項等を引くこ とによって外力トルクを推定するものである。図 7 におい て $J_{m}, K_{t}$ はそれぞれモー夕軸慣性, トルク定数, 右下添 え字の $n$ はノミナル值を表し,$G_{r}$ はギア比, $G_{r t o}$ はローパ スフィルタのカットオフ周波数を表す。

反力推定オブザーバの特徵としてはモータの摩擦の影響 を受けやすいことが挙げられる。パラレルリンクマニピュ 


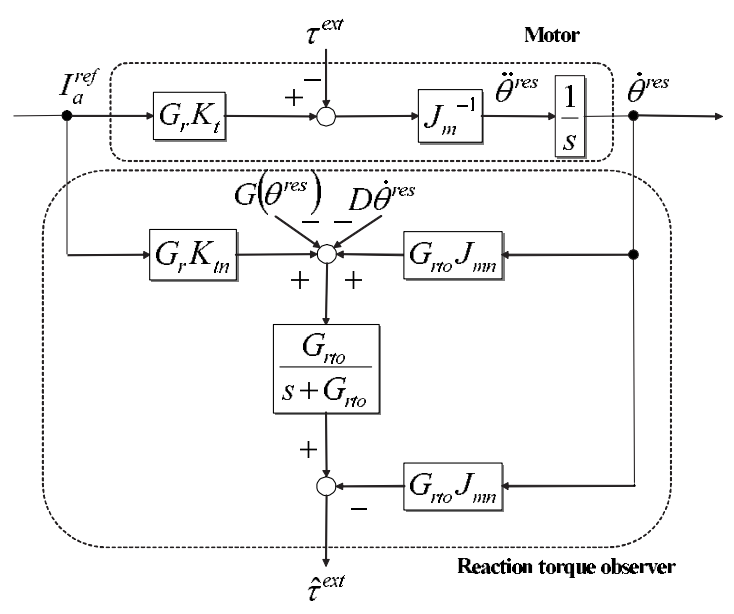

図 7 反力推定オブザーバ

Fig. 7. Reaction torque observer

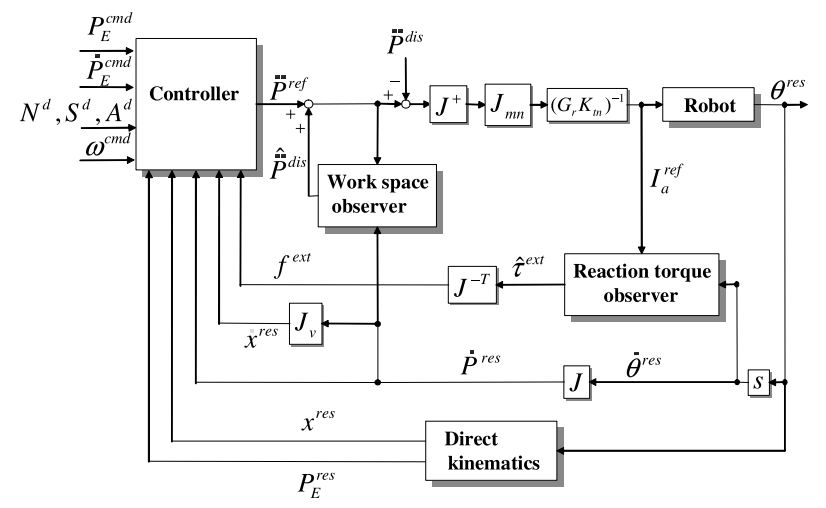

図 8 全体の制御系

Fig. 8. Total control system

レータは駆動関節にツインドライブシステム ${ }^{(13)}$ を採用する ことで，関節に動力を伝達する際に発生する非線形の静止 摩擦およびクーロン摩擦の影響を抑えている。したがって, 非線形摩擦の影響を受けずに，高精度に反力を推定するこ とが可能となる。

〈4·3〉 全体の制御系 接触位置推定のために用いる全 体の制御系を図 8 に示す。作業空間での制御においてロバ ストな加速度制御系を実現するため，作業空間オブザーバ (WDOB : Work space Disturbance OBserver) ${ }^{(14)}$ を用いる。

\section{5. シミュレーション}

〈5・1〉 シミュレーション内容シミュレーションはエ ンドエフェクタ上の 1 点 $(x, y, z)=(0.015,0.015,0.4)$ に $5 \mathrm{~N}$ の力を $z$ 方向へステップ入力することにより行った。この とき，エンドエフェクタの中心に関しては常に $(0.0,0.0,0.4)$ に位置制御を行い，姿勢の指令值はベース座標系の $x y$ 平面 と平行となるように設定した。ただし本論文では，座標表 示はベース座標系を基準とし，単位は $[\mathrm{m}]$ とする。シミュ レーションで使用したパラメータを表 1 に示す。

〈5・2〉 シミュレーション結果シミュレーション結 果を図 9 に示す。図 9(a), (b) はそれぞれ各アーム先端の
表 1 使用したパラメータ

Table 1. Parameters

\begin{tabular}{l|c|rl}
\hline \hline Posotion feedback gain & $K_{P}$ & 900 & \\
Velocity feedback gain & $K_{V}$ & 60 & \\
Cut-off frequency of JDOB & $G_{j}$ & 80 & {$[\mathrm{rad} / \mathrm{s}]$} \\
Cut-off frequency of WDOB & $G_{w d}$ & 80 & {$[\mathrm{rad} / \mathrm{s}]$} \\
Cut-off frequency of RTOB & $G_{r t o}$ & 30 & {$[\mathrm{rad} / \mathrm{s}]$} \\
Virtual mass & $M_{c}$ & 1 & {$[\mathrm{~kg}]$} \\
Virtual damping & $D_{c}$ & 40 & {$[\mathrm{Ns} / \mathrm{m}]$} \\
Virtual stiffness & $K_{c}$ & 400 & {$[\mathrm{~N} / \mathrm{m}]$} \\
\hline
\end{tabular}

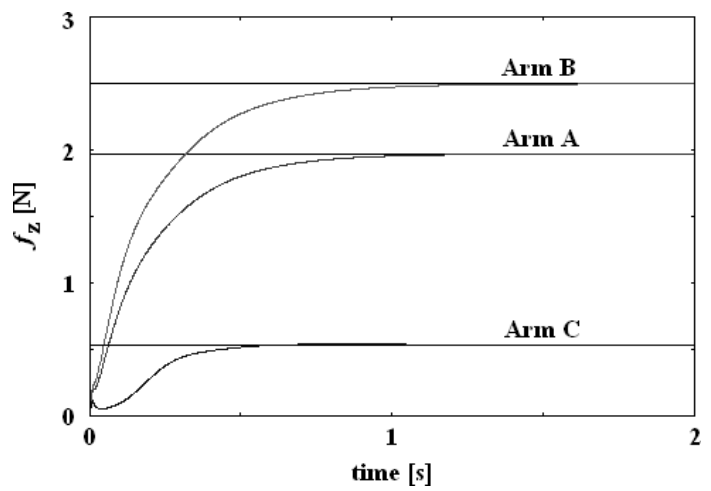

(a) Force response

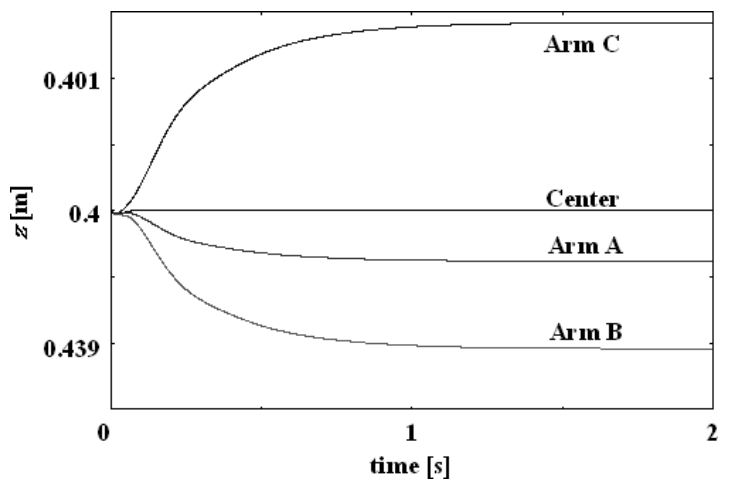

(b) Position response

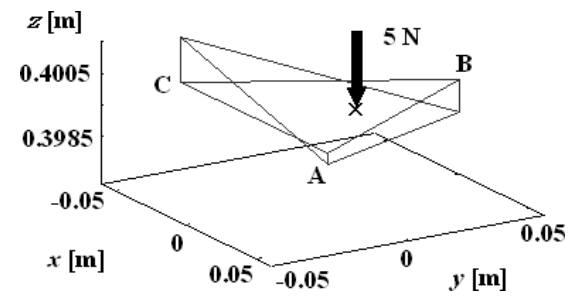

(c) Attitude response

図 9 姿勢コンプライアンス制御のシミュレー ション結果 $\left(K_{f}=0.5\right)$

Fig. 9. Simulation results in the case of attitude compliance control $\left(K_{f}=0.5\right)$

力応答，位置応答であり，図 9(c) はエンドエフェクタの姿 勢変化を表している。提案した制御器を用いることにより, エンドエフェクタに外力が加わった場合, 外力の大きさに 応じて各アーム先端の位置が変化していることがわかる。 一方，姿勢にコンプライアンスを入れても，エンドエフェ クタの中心に対しては位置制御を行っているため, 図 9(b) 
に示すように，エンドエフェクタの中心は $(0.0,0.0,0.4)$ か ら変化していない。

\section{6. 実験}

〈6・1〉 実験内容 エンドエフェクタを初期位置 $(0.0$, $0.0,0.4)$ から $z$ 方向へと移動させ，環境と接触させた。ま た，姿勢の指令值はべース座標系の $x y$ 平面と平行となるよ うに設定し，パラメータはシミュレーションと同じ表 1 に 示す值を使用した。なお，エンドエフェクタと環境はエン ドエフェクタ上のある 1 点で接触するものと仮定する。接 触位置の推定は 3 秒間のデータから 0.1 秒間隔で 30 個選 び，行った。

〈6・2〉 実験結果＼cjkstart環境の座標が $(0.019,0.015,0.4017)$, エンドエフェクタの中心の位置指令值が $(0.0,0.0,0.4037)$ の場合の実験結果を図 10 に示す。図 10(a), (b) はそれぞ れ各アーム先端の力応答, 位置応答であり, 図 10(c) はエン ドエフェクタの姿勢变化を表している。接触した瞬間に各 アームに大きな力が加わり，位置も変化していることがわ かる。図 10(a)，(b)より，定常状態では外力の大きさに応 じて各アーム先端の位置が変化していることがわかる。し かし，図 10(b) に示すように，エンドエフェクタの中心に は位置制御を行っているため, $(0.0,0.0,0.4037)$ から変化 していない。

図 11 にエンドエフェクタの姿勢に対して位置制御 $\left(K_{f}=\right.$ $0.0)$ を行った場合とコンプライアンス制御 $\left(K_{f}=1.0\right)$ を行っ た場合のエンドエフェクタ中心の位置応答を示す。図 11(a) より，エンドエフェクタの姿勢に対して位置制御を行った 場合には環境との接触時に位置応答が振動的になり, いわゆ るチャタリングが生じていることがわかる。一方, 図 11(b) より，エンドエフェクタの姿勢にコンプライアンス制御を 行った場合にはチャタリングが少なく，安定な接触をして いることがわかる。したがって，提案したコンプライアン ス制御器を用いた方が実験機や環境に対して負荷が少ない と考えられる。

次に, 推定された接触位置と実際の環境との距離 $d$ を求 め, 侵入量 $\alpha$ による推定精度の比較を行った。結果を困 12 に示す。ここで，侵入量 $\alpha$ とは，エンドエフェクタが環境 と接触した後のエンドエフェクタの中心の $z$ 方向移動量を 意味するものとする。つまり，環境の $z$ 座標は 0.4017 であ るので, 侵入量 $\alpha$ はエンドエフェクタの中心の $z$ 座標から 0.4017 を引いた值となる。また, 環境からの反力と侵入量 $\alpha$ との関係を図 13 に示す。

図 12 より，K $K_{f}$ の大きさに関わらず，侵入量 $\alpha$ を大きく すると推定精度は上がることがわかる。これは, 図 13 で示 すように侵入量 $\alpha$ が大きくなると環境からの反力が大きく なり，各アームに加わる力の比がノイズに埋もれず，より 正確に検出できるためである。同じ侵入量 $\alpha$ で比べると, コンプライアンス制御 $\left(K_{f}>0.0\right)$ の場合よりも環境から 大きな反力が得られる位置制御 $\left(K_{f}=0.0\right)$ の場合の方が 推定精度は良い。一方，図 12 より，コンプライアンス制御

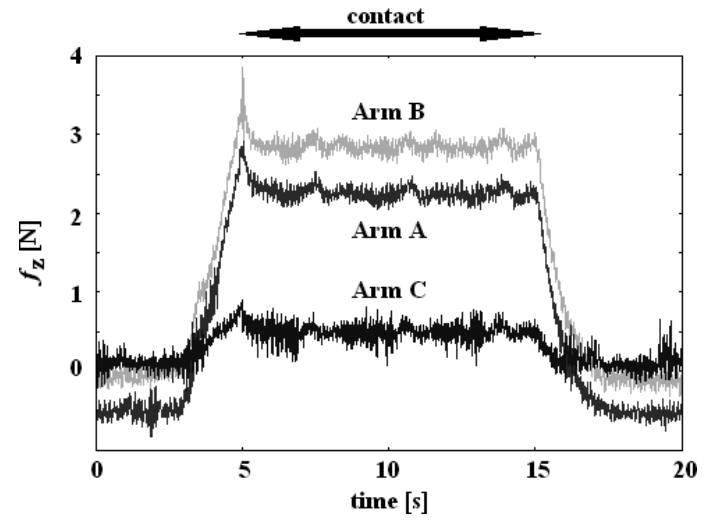

(a) Force response

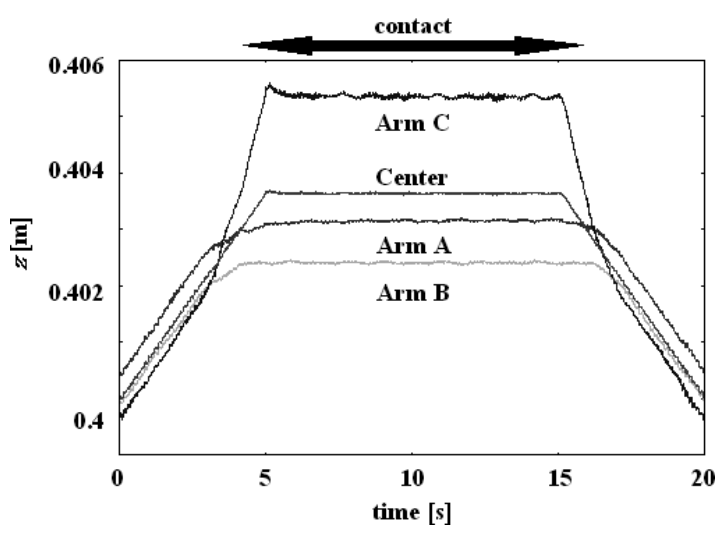

(b) Position response

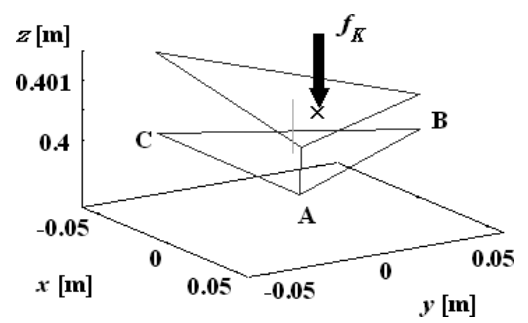

(c) Attitude response

図 10 姿勢コンプライアンス制御の実験結果 $\left(K_{f}=0.5\right)$ Fig. 10. Experimental results in the case of attitude compliance control $\left(K_{f}=0.5\right)$

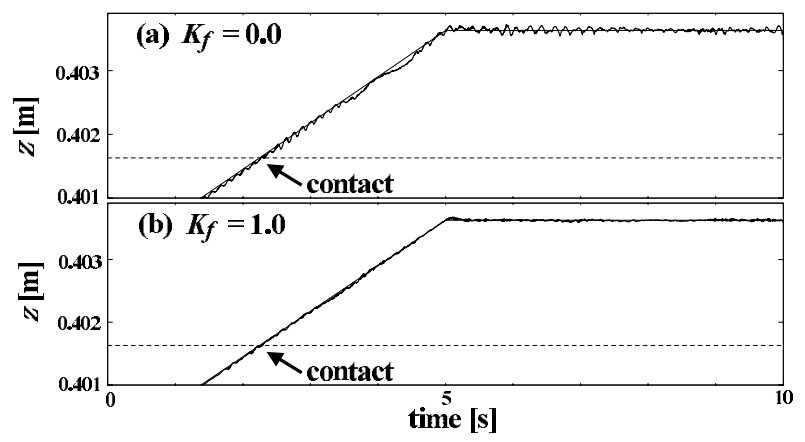

図 11 位置制御とコンプライアンス制御の比較 $(\alpha=2 \mathrm{~mm})$

Fig. 11. Comparison of position control with compliance control $(\alpha=2 \mathrm{~mm})$ 


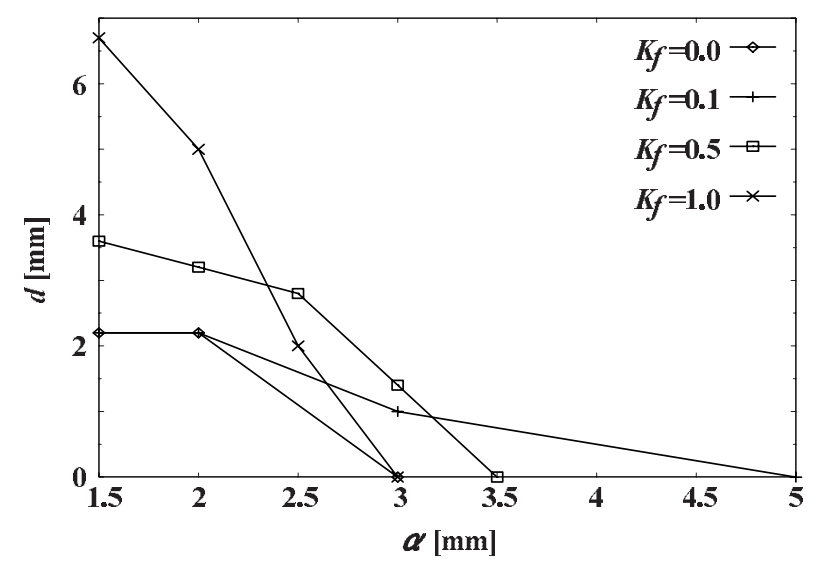

図 12 推定精度の比較

Fig. 12. Comparison of estimation accuracy

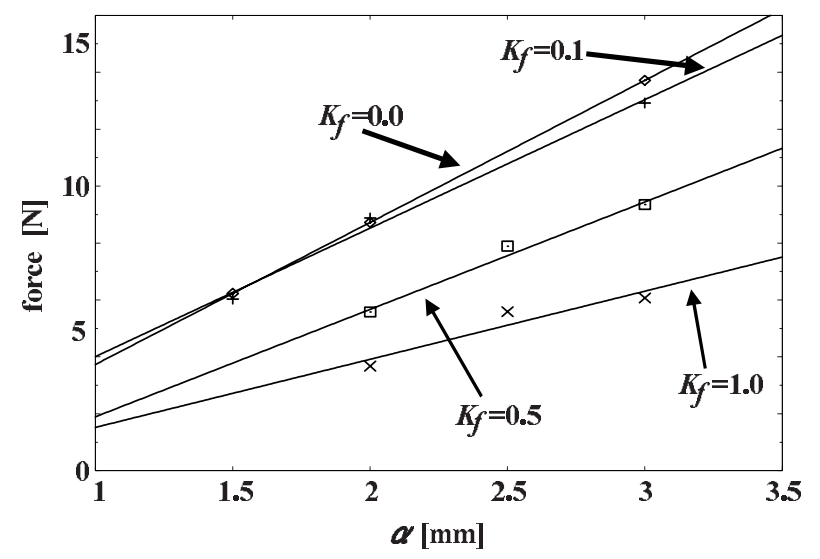

図 13 反力の大きさの比較

Fig. 13. Comparison of reaction force

$\left(K_{f}=1.0\right)$ を行った場合, 侵入量が $3 \mathrm{~mm}$ 程度あれば，位 置制御を行った場合と比べて小さな反力で精度良く推定で きていることがわかる。以上から，提案した制御手法を用 いることにより，環境に与える力が小さくても接触位置が 推定できることが示された。

\section{7. 結 論}

本論文では，平面状エンドエフェクタを用いることによ り従来の球状エンドェフェクタでは実現できなかった面一 点接触を可能とした。エンドエフェクタと環境との接触状 態が面一点接触である場合について，エンコーダより得られ た位置情報と反力推定オブザーバによりセンサレスで計算 された力情報から，エンドエフェクタと環境との接触位置 を推定する方法を提案した。また，環境と安定な接触をし， 環境に大きな負荷を与えず接触位置を推定するためにエン ドエフェクタの中心には位置制御，姿勢にはコンプライア ンス制御を行う制御器を提案した。

シミュレーションと実験により提案した接触位置推定法 及び制御手法の有効性を確認した。エンドエフェクタ上の 一点に外力を加えるシミュレーションおよび実験では，エ ンドエフェクタの中心には位置制御，姿勢にはコンプライ
アンス制御が行えていることを確認した。エンドエフェク 夕の姿勢にコンプライアンス制御を行った場合には，位置 制御を行った場合に比べてチャタリングの少ない安定な接 触が実現できた。また, 接触位置推定の実験では, 提案し た制御器を用いることにより, 環境に与える力が小さくて も接触位置が高精度に推定できることがわかった。

本論文で提案した接触位置推定法は，ロボットハンドの 手の平や歩行ロボットの足平（足の裏の平面部）が環境や 地面と接触する場合に, ロボットが環境や地面を認識する 手段となりうる。提案した姿勢制御手法は, パラレルメカ ニズムによって支持される平面状エンドエフェクタの姿勢 に対して所望のコンプライアンス特性を持たせることがで きるため, 人間に過剰な力を与えずに触診を行わなければ ならない医療用ロボットなどへの適用が期待できる。

ロボットが面一面接触, 面一線接触, 面一点接触の 3 つの 状態を判別し, 平面状エンドエフェクタを通して接触して いる環境の形状を把握できるようになることが今後の課題 である。

\section{謝 辞}

本研究の一部は日本学術振興会科学研究費補助金（課題 番号 17206027 基盤研究（A）「リニアモー夕駆動による 低侵襲性医療用多自由度触覚鉗子の開発研究」）によって行 われたことを記し，関係各位に謝意を表す。

(平成 17 年 8 月 22 日受付, 平成 18 年 2 月 20 日再受付)

\section{文献}

(1) M. Vukobratović and A. Tuneski: "Contact Control Concepts in Manipulation Robotics - An Overview", IEEE Transactions on Industrial Electronics, Vol.41, No.1, pp.12-24 (1994)

(2) T. Sakaki and S. Tachi: "Contact Stability Analysis on Some Impedance Control Methods", Journal of the RSJ, Vol.12, No.3, pp.489-496 (1994-3) (in Japanese)

榊 泰輔・舘 暲:「インピーダンス制御の接触安定性について の一考察」, 日本ロボット学会誌, 12, 3, pp.489-496 (1994-3)

(3) G. Ferretti, G.A. Magnani, and P. Rocco: "Impedance Control for Elastic Joints Industrial Manipulators", IEEE Transactions on Robotics and Automation, Vol.20, No.3, pp.488-498 (2004)

(4) H. Ishikawa, C. Sawada, K. Kawase, and M. Takata: "Stable Compliance Control and Its Implitshapeentation for a 6 D.O.F Manipulator", Proceedings of the IEEE International Conference on Robotics and Automation, pp.98-103 (1989)

(5) S. Katsura and K. Ohnishi: "Transmission and Reproduction of Force Sensation by Bilateral Control", T. IEE Japan Trans. IA, Vol.123-D, No.11, pp.1371-1376 (2003-11) (in Japanese) 桂誠一郎・大西公平：「バイラテラル制御による力覚の伝達と再現」, 電学論 D, 123, 11, pp.1371-1376 (2003-11)

(6) I. Kato, K. Koganezawa, and A. Takanishi: "Automatic Palpation Systitshape for Breast Cancer: WAPRO-4", Journal of the RSJ, Vol.5, No.2, pp.18-24 (1987-4) (in Japanese) 加藤一郎・小金沢鋼一・高西淳夫：「乳ガン自動触診ロボット・WAPRO4」, 日本ロボット学誌, 5, 2, pp.18-24 (1987-4)

(7) M. Morisawa, T. Murakami, and K. Ohnishi: "Motion Control of Parallel Mechanism in Workspace", Journal of the JSPE, Vol.70, No.2, pp.203-208 (2004-2) (in Japanese)

森澤光晴・村上俊之・大西公平:「パラレルメカニズムの作業空間にお けるモーションコントロール」, 精密工学誌, 70, 2, pp.203-208 (2004-2)

(8) T. Murakami, F. Yu, and K. Ohnishi: "Torque Sensorless Control in Multidegree-of-Freedom Manipulator", IEEE Transactions on Industrial Electronics, Vol.40, No.2, pp.259-265 (1993)

（9） THK 株式会社：「直動システム 総合カタログ 製品諸元」, No.401-2004, 
pp.T1-T20 (2004)

(10) Y.K. Yiu, H. Cheng, Z.H. Xiong, G.F. Liu, and Z.X. Li: "On the Dynamics of Parallel Manipulators", Proc. of the IEEE International Conference on Robotics and Automation, pp.3766-3771 (2001)

(11) N. Nishikawa, Y. Fujimoto, T. Murakami, and K. Ohnishi: "Variable Compliance Control for 3 Dimensional Biped Robot Considering Environmental Fluctuations", T. IEE Japan Trans. IA, Vol.119-D, No.12, pp.1507-1514 (1999-12) (in Japanese)

西川直樹・藤本康孝・村上俊之・大西公平：「環境変動を考慮した 3 次元 2 足歩行ロボットの可変コンプライアンス制御」, 電学論 $\mathrm{D}$, 119, 12, pp.1507-1514 (1999-12)

(12) K. Ohnishi, M. Shibata, and T. Murakami: "Motion Control for Advanced Mechatronics", IEEE/ASME Trans. on Mechatronics, Vol.1, No.1, pp.56-67 (1996)

(13) N. Hayashida, T. Yakoh, T. Murakami, and K. Ohnishi: "A Sensorless Force Control in Twin Drive Systitshape", Proc. of the IEEE Int. Conference on Industrial Electronics, Control and Instrumentation (IECON-2000), pp.22312236 (2000)

(14) T. Murakami and K. Ohnishi: "A Study of Stability and Workspace Decoupling Control Based on Robust Control in Multi-Degrees-of-Freedom Robot", IEEJ Trans. IA, Vol.113-D, No.5, pp.639-646 (1993-5) (in Japanese)

村上俊之・大西公平：「ロバスト制御に基づいた多自由度ロボット の安定性および作業空間での非干渉制御に関する一考察」, 電学論 D, 113, 5, pp.639-646 (1993-5)
久 保 亮 吾 (学生員) 1983 年 1 月 13 日生。 2005 年 3 月慶

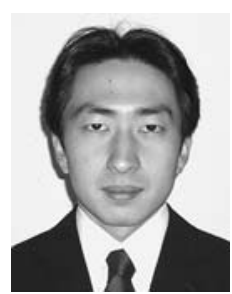
應義塾大学理工学部システムデザイン工学科卒業。 同年 4 月同大学大学院理工学研究科総合デザイン 工学専攻修士課程入学。現在，主として環境適応 型ロボットのモーションコントロールに関する研 究に従事。

大 西 公 平 (上級会員) 1952 年 7 月 25 日生。 1980 年 3 月

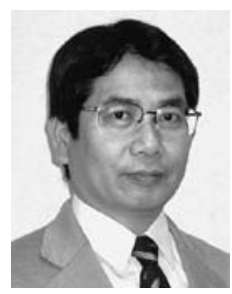
東京大学大学院丁学系研究科電気丁学専攻博十課 程修了。同年 4 月慶應義塾大学理工学部電気工学 科助手。現在, 理工学部システムデザイン工学科 教授。工学博士。 